\title{
Use of Lactobacillus plantarum as Starter Culture and Its Influence on Physicochemical, Microbiological, and Sensory Characteristics of Kunnu-Aya Produced from Sorghum and Tigernut
}

\author{
O. A. Olaoye, J. Ndife, and V. I. Raymond \\ Department of Food Science and Technology, Michael Okpara University of Agriculture, Umudike, Abia State, Nigeria
}

Correspondence should be addressed to O. A. Olaoye; olaayosegun@yahoo.com

Received 4 October 2017; Accepted 15 November 2017; Published 25 December 2017

Academic Editor: Elena González-Fandos

Copyright (C) 2017 O. A. Olaoye et al. This is an open access article distributed under the Creative Commons Attribution License, which permits unrestricted use, distribution, and reproduction in any medium, provided the original work is properly cited.

\begin{abstract}
Kunun-aya is a traditional nonalcoholic beverage in the northern part of Nigeria, normally prepared from cereals. In this investigation Lactobacillus plantarum, isolated from fermenting kunun, was applied as starter culture during production of kununaya from varying combinations of sorghum and tigernut. The quality attributes of the product indicated increase in ash and protein contents of product inoculated with starter culture (PISC) over the uninoculated control sample (UCS). The highest values of $4.43 \%$ and $6.95 \%$ were recorded for ash and protein, respectively, in the product from fifty percent each of sorghum and tigernut (50SOR/50TIG). Titratable acidity was higher in PISC compared to UCS; the 50SOR/50TIG sample had the highest value of 0.92. The PISC recorded reduced counts of Salmonella, coliforms, and Staphylococci. The SCIS were preferred by panellists in the sensory attributes of appearance, aroma, taste, mouthfeel, and general acceptability. It was concluded that the use of L. plantarum as starter culture in the production of kunun-aya was advantageous as a result of enhanced nutritional, sensory, and microbial qualities recorded compared to UCS. Reduction in Salmonella, coliforms, and Staphylococci in PISC may be of public health significance. This on quality improvement of the traditional beverage has not been previously reported.
\end{abstract}

\section{Introduction}

Kunun is a traditional fermented nonalcoholic cereal beverage widely consumed in Northern Nigeria and other countries of West Africa, which can be produced from either millet, sorghum, or maize [1]. When the beverage is produced from any of the cereals along with tigernut (called aya in Hausa, a language commonly spoken in the northern parts of Nigeria), the name could be qualified and called kunun-aya. The beverage is believed to be of immense social, economic, nutritional, and medicinal importance to consumers. It is generally regarded as a refreshing drink during the dry season because of its thirst quenching properties [2]. The process of production involves wet milling of the cereal, wet sieving, partial gelatinization of the slurry, mild fermentation, sugar addition, and bottling. Olaoye et al. [2] investigated the microbial composition of kunun enriched with tigernut milk extract; the authors reported that the associated bacteria and yeast and molds in the beverage ranged from 2 to $3 \log \mathrm{CFU} / \mathrm{g}$.

The occurrence of Lactobacillus plantarum in cereals and fermented cereal products has been reported by many research investigators. Okoronkwo [3] reported the isolation and identification of $L$. plantarum during fermentation of millet and sorghum into burukutu and kunun-zaki. In another study, Adeyemo and Onilude [4] isolated and identified $L$. plantarum from ogi, a fermented cereal product from maize and sorghum, during fermentation. It has thus become important that the occurrence of L. plantarum in cereals, especially during production of fermented products from them, may be very significant as the organism has been noted to play vital roles in fermentation stages $[3,4]$.

Tigernut (Cyperus esculentus L.) belongs to the family Cyperaceae and has been identified as a cosmopolitan and perennial crop. The tubers are about the size of peanut and 
are abundantly produced in Nigeria and other countries in West Africa. In Nigeria, the Hausas call it aya, Yoruba imumu, and Igbo aki Hausa while it is called offio in Southern Nigeria. Tigernut has been cultivated since early times in South Europe and West Africa for its small tuberous rhizomes which are eaten raw or roasted or pressed to extract juice in making beverage. Tigernut is valued for its dietary fibre content, protein, and also mineral content [5]. As a result of its high dietary fibber content, tigernut could be effective in the treatment and prevention of many diseases such as colon cancer, coronary heart disease, obesity, diabetes, and gastrointestinal disease. It is rich in protein, reducing sugar and soluble polysaccharides.

Lactic acid bacteria (LAB) are important group of microorganisms which can secrete antimicrobial substances in foods, some of which may have antagonistic activities against foodborne pathogens and spoilage organisms [6]. According to Calo-Mata et al. [7], LAB may be used to promote food safety, preserve food quality, develop characteristic new flavors, and improve the nutritional qualities of foods. Some strains of LAB belonging to genera Leuconostoc, Lactococcus, Pediococcus, and Lactobacillus have been used as starter cultures (and are still being exploited) in the processing of many fermented food products [8].

Many research investigations have been reported on the use of LAB as starter cultures in the processing and preservation of meat $[6,9-11]$, vegetables [12-14], and dairy [15]. However, research is limited on the use of LAB cultures in the Nigerian traditional vegetable kunun-aya and therefore more research investigations are required in possible quality improvement of the product with the use of biological agents. The present report was therefore aimed at investigating the influence of Lactobacillus plantarum as starter culture some quality characteristics of kunun-aya produced from sorghum and tigernut.

\section{Materials and Methods}

2.1. Sources of Raw Material. The sorghum grains (Sorghum bicolor) used in this study were obtained from National Stored Products Research Institute (NSPRI), Port Harcourt, Rivers State, Nigeria; and sweet potatoes (Ipomoea botatas) was procured from the National Root Crop Research Institute (NRCRI), Umudike, Abia State, Nigeria. Tigernuts (Cyperus esculentus), date palm fruit (Phoenix dactylifera), spices (ginger and pepper), and sugars were purchased from a local market in Umuahia Township, Abia State, Nigeria.

\subsection{Isolation of Lactobacillus plantarum and Culture Condi-} tions. The LAB strain, Lactobacillus plantarum used as starter culture in the present report was isolated from fermenting kunun which had been spontaneously initiated using the method described in previous studies $[2,16]$. Ten millilitres $(10 \mathrm{ml})$ of the fermenting medium was homogenized in $90 \mathrm{ml}$ sterile distilled water (SDW) in a stomacher (Standard Bags, Stomacher LAB System, Seward Circular 400, UK) for about $2 \mathrm{~min}$. A further tenfold dilution was the resulting homogenate which was made by mixing $1 \mathrm{ml}$ with $9 \mathrm{ml}$
SDW, from which $1 \mathrm{ml}$ was pour plated in MRS agar media (Oxoid, UK) and incubated in anaerobic jar at $37^{\circ} \mathrm{C}$ for 48-72 h. Resulting colonies were screened by microscopic examination, after which successful ones were subjected to biochemical tests including sugar fermentation and catalase and oxidase tests among others. Lactobacillus plantarum was identified from the screened pure colonies with reference to Bergey's Manual of Systematic Bacteriology (Sneath et al., 1986). The culture was screened for ability to produce considerate quantities of lactic and acetic acids using the method described in a previous study [6]. Pure culture of Lactobacillus plantarum was routinely maintained in MRS broth medium (Oxoid, UK) containing $20 \%$ glycerol at $-20^{\circ} \mathrm{C}$ as working culture; while, for long-term storage, it was maintained in the same medium at $-80^{\circ} \mathrm{C}$.

2.3. Production of Kunun-Aya. Kunun-aya was produced using the method described by Olaoye et al. [2], with some modification as represented in Figure 1. Weighed quantities of healthy sorghum grains $(1 \mathrm{~kg})$ were washed to remove stones and other dirt; they were thereafter steeped in clean water for $48 \mathrm{~h}$ to soften the testas. The grains then were wet milled along with spices ( $65 \mathrm{~g}$ ginger, $10 \mathrm{~g}$ red pepper, and $15 \mathrm{~g}$ sweet potatoes) into a slurry, to which three parts of boiled water $\left(\sim 40^{\circ} \mathrm{C}\right)$ were added and thoroughly mixed. The resulting solution was sieved using a muslin cloth to obtain sorghum extract (SE).

Healthy tigernuts $(1 \mathrm{~kg})$ were washed to remove dirt. They were subjected to blanching $\left(75^{\circ} \mathrm{C}, 30 \mathrm{~min}\right)$ and then washed in clean water. The nuts were then boiled in $0.2 \%(\mathrm{w} / \mathrm{v})$ solution of sodium bicarbonate for $30 \mathrm{~min}$ to reduce objectionable flavor. They were drained, mixed with water (ratio 1:4), and milled (Philips-Kenwood, UK). The homogenous slurry was filtered using a muslin cloth to obtain tigernut milk extract (TME).

SE and TME were mixed in respectively $90: 10,80: 20$, $70: 30,60: 40$, and $50: 50$. Each mixture was divided into two equal parts; one part was inoculated with $1 \times 10^{4} \mathrm{CFUs} / \mathrm{ml}$ of $L$. plantarum as starter culture while the other part was not inoculated with the starter culture. The two parts were fermented for $12 \mathrm{~h}$ and then pasteurized $\left(75^{\circ} \mathrm{C}\right.$ for $\left.15 \mathrm{~min}\right)$ to terminate the fermentation process. The resulting liquid was kunun-aya which was sweetened by the addition of sucrose $(5 \% \mathrm{w} / \mathrm{v})$.

\subsection{Determination of Proximate Composition of Kunun-} Aya. The proximate composition of the kunun-aya samples, including moisture, ash, fat, and protein contents, was carried out using the methods of Association of Official Analytical Chemists [17]. Carbohydrate was determined by difference.

2.5. Determination of Physicochemical Properties of KununAya. The total soluble solids (TSS) in the kunun-aya samples were determined by slight modification of the method described by Olaoye et al. [2]. Exactly $25 \mathrm{ml}$ of sample was measured into porcelain of known weight and evaporated 


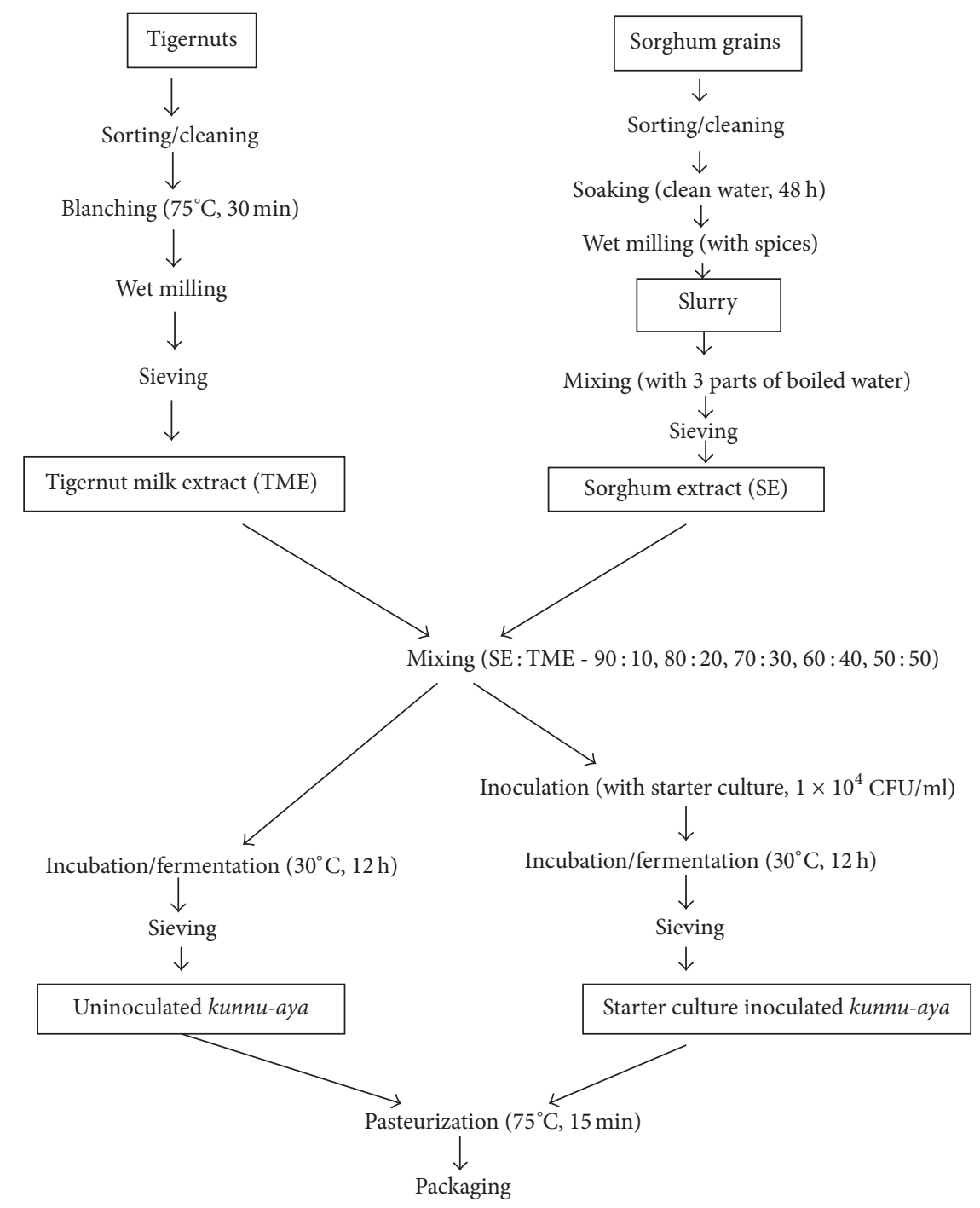

FIGURE 1: Flow chart for production of starter culture inoculated and uninoculated kunun-aya.

over boiling water in a water bath. The evaporated sample was dried to constant weight in an oven at $120 \pm 5^{\circ} \mathrm{C}$ for $3 \mathrm{~h}$

$$
\begin{aligned}
& \% \text { Total soluble solids } \\
& =\frac{\text { Weight of dried sample } \times 100}{\text { Weight of original sample }} .
\end{aligned}
$$

Specific gravity (SG), $\mathrm{pH}$, and titratable acidity (TTA) of the samples were determined according to the methods of AOAC [17].

2.6. Determination of Microbiological Properties. A tenfold dilution of kunun-aya was made by taking ten milliliters and thoroughly mixing it in $90 \mathrm{ml}$ of sterile distilled water $\left(10^{-1}\right.$ dilution); from this, further dilutions were made. One milliliter $(1 \mathrm{ml})$ of appropriate dilutions was mixed with appropriate sterile molten media $\left(45^{\circ} \mathrm{C}\right)$; potato dextrose agar (PDA) for molds; malt extract agar (MEA) supplemented with streptomycin for yeast; MacConkey agar for coliforms; plate count agar (PCA) for total bacteria count; deMan Rogosa Sharpe agar (MRS) for LAB; xylose lysine deoxycholate (XLD) for Salmonella; and Mannitol salt agar for Staphylococcus.

Incubation period was $48 \mathrm{~h}$ at $37^{\circ} \mathrm{C}$, except for yeast and molds $\left(25^{\circ} \mathrm{C}, 72 \mathrm{~h}\right)$. Determinations were carried out in triplicate and counts were expressed in logarithmic of colony forming unit per milliliter of sample (i.e., $\log \mathrm{CFUs} / \mathrm{ml}$ ).

2.7. Determination of Sensory Properties. The sensory properties, including appearance, aroma, taste, mouthfeel, and general acceptability, of kunun-aya samples were determined using a semitrained fifty-member panel ranging between twenty and fifty years of age and composed of 31 males and 19 females. The panelists were asked to allocate scores to each attribute based on a 9-point hedonic scale ranging from 1 (dislike extremely) to 9 (like extremely). Data collected were subjected to statistical analysis to determine possible differences among samples. 
TABLE 1: Proximate composition of starter culture inoculated and uninoculated kunnu-aya.

\begin{tabular}{|c|c|c|c|c|c|}
\hline \multirow{2}{*}{ Samples } & \multicolumn{5}{|c|}{ Proximate parameters } \\
\hline & Moisture & Ash & Fat & Protein & Carbohydrate \\
\hline \multicolumn{6}{|c|}{ Inoculated samples } \\
\hline 100SOR/0TIG & $86.80 \pm 0.01^{\mathrm{a}}$ & $2.91 \pm 0.22^{\mathrm{b}}$ & $2.32 \pm 0.02^{\mathrm{b}}$ & $5.01 \pm 0.01^{\mathrm{d}}$ & $2.96 \pm 0.08^{\mathrm{a}}$ \\
\hline 90SOR/10TIG & $85.44 \pm 0.01^{\mathrm{a}}$ & $3.18 \pm 0.21^{\mathrm{b}}$ & $2.91 \pm 0.10^{\mathrm{a}}$ & $5.35 \pm 0.06^{\mathrm{C}}$ & $3.12 \pm 0.33^{\mathrm{a}}$ \\
\hline 80SOR/20TIG & $84.33 \pm 0.01^{\mathrm{ab}}$ & $3.74 \pm 1.23^{\mathrm{ab}}$ & $2.88 \pm 0.69^{\mathrm{a}}$ & $5.58 \pm 0.09^{b}$ & $3.47 \pm 0.01^{\mathrm{a}}$ \\
\hline 70SOR/30TIG & $83.31 \pm 0.01^{\mathrm{b}}$ & $3.99 \pm 0.42^{\mathrm{a}}$ & $2.93 \pm 0.07^{\mathrm{a}}$ & $5.83 \pm 0.18^{\mathrm{b}}$ & $3.94 \pm 0.16^{\mathrm{a}}$ \\
\hline $60 \mathrm{SOR} / 40 \mathrm{TIG}$ & $83.40 \pm 0.00^{\mathrm{b}}$ & $4.28 \pm 0.17^{\mathrm{a}}$ & $3.39 \pm 0.07^{\mathrm{a}}$ & $6.06 \pm 0.06^{\mathrm{ab}}$ & $2.87 \pm 0.16^{\mathrm{b}}$ \\
\hline 50SOR/50TIG & $82.26 \pm 0.01^{\mathrm{b}}$ & $4.43 \pm 0.55^{\mathrm{a}}$ & $3.37 \pm 0.01^{\mathrm{a}}$ & $6.95 \pm 0.14^{\mathrm{a}}$ & $2.99 \pm 0.01^{\mathrm{a}}$ \\
\hline \multicolumn{6}{|c|}{ Uninoculated samples } \\
\hline 100SOR/0TIG & $88.93 \pm 0.00^{\mathrm{a}}$ & $2.05 \pm 0.75^{\mathrm{d}}$ & $2.29 \pm 0.89^{\mathrm{b}}$ & $4.40 \pm 0.01^{\mathrm{e}}$ & $2.33 \pm 0.01^{\mathrm{b}}$ \\
\hline 90SOR/10TIG & $87.40 \pm 0.28^{\mathrm{a}}$ & $2.12 \pm 0.07^{\mathrm{d}}$ & $2.83 \pm 0.53^{\mathrm{a}}$ & $4.72 \pm 0.11^{\mathrm{d}}$ & $2.93 \pm 0.08^{\mathrm{a}}$ \\
\hline 80SOR/20TIG & $86.76 \pm 0.01^{\mathrm{a}}$ & $2.24 \pm 0.01^{\mathrm{cd}}$ & $2.67 \pm 1.01^{\mathrm{a}}$ & $4.93 \pm 0.03^{\mathrm{d}}$ & $3.40 \pm 0.06^{\mathrm{a}}$ \\
\hline 70SOR/30TIG & $86.03 \pm 0.32^{\mathrm{a}}$ & $2.38 \pm 0.04^{\mathrm{c}}$ & $2.68 \pm 0.74^{\mathrm{a}}$ & $5.03 \pm 0.03^{\mathrm{d}}$ & $3.88 \pm 0.07^{\mathrm{a}}$ \\
\hline $60 \mathrm{SOR} / 40 \mathrm{TIG}$ & $86.78 \pm 0.37^{\mathrm{a}}$ & $2.41 \pm 0.85^{\mathrm{c}}$ & $3.33 \pm 0.82^{\mathrm{a}}$ & $5.21 \pm 0.03^{\mathrm{c}}$ & $2.27 \pm 0.03^{\mathrm{b}}$ \\
\hline 50SOR/50TIG & $86.22 \pm 0.07^{\mathrm{a}}$ & $2.48 \pm 0.34^{\mathrm{c}}$ & $3.35 \pm 0.25^{\mathrm{a}}$ & $5.64 \pm 0.09^{b}$ & $2.31 \pm 0.08^{\mathrm{b}}$ \\
\hline
\end{tabular}

Values are means of three replicated samples. Means with different superscript letters across columns are significantly different $(p<0.05) ; 100 \mathrm{SOR} / 0 \mathrm{TIG}, 100 \%$ sorghum and $0 \%$ tigernut; 90 SOR/10TIG, $90 \%$ sorghum and $10 \%$ tigernut; 80 SOR/20TIG, $80 \%$ sorghum and $20 \%$ tigernut; 70 SOR/30TIG, $70 \%$ sorghum and $30 \%$ tigernut; $60 \mathrm{SOR} / 40 \mathrm{TIG}, 60 \%$ sorghum and $40 \%$ tigernut; $50 \mathrm{SOR} / 50 \mathrm{TIG}, 50 \%$ sorghum and $50 \%$ tigernut.

2.8. Statistical Analysis. The emanating data which depended on inoculation of starter culture on kunun-aya were analyzed according to a completely randomized design with three replicates. Data were subjected to variance analyses and differences between means were evaluated by Duncan's multiple range test using SPSS statistic programme, version 10.01 [18]. Significant differences were expressed at $p<0.05$.

\section{Results and Discussion}

3.1. Lactobacillus plantarum Used as Starter Culture. In the present study, a LAB strain Lactobacillus plantarum used as starter culture during fermentation process in the production of kunnu-aya was isolated from fermenting kunun. The isolation and identification of the L. plantarum were done following methods which had been previously reported by other research investigators $[2,16]$. The subsequent selection of this LAB strain as starter culture was due to its ability to produce considerable concentrations of lactic and acetic acids during preliminary experiments. Olaoye et al. [2] also reported the ability of the LAB strain to produce considerate quantities of lactic and acetic acids. According to the authors, L. plantarum produced 27.99 and $3.48 \mathrm{~g} / 10^{7} \mathrm{CFUs}$ of the respective acids, giving it an advantage to be used as starter culture. This observation was similar to those observed in the present study where $L$ plantarum produced lactic and acetic acid concentrations of 27.07 and $3.36 \mathrm{~g} / 10^{7}$ CFUs, respectively. The concentration of lactic acid produced by LAB could contribute to preservation of food products by bringing about antagonism against food spoilage organisms $[2,8,19]$. The L. plantarum was noted to produce reduced concentration of acetic acid ( $\left.<4 \mathrm{~g} / 10^{7} \mathrm{CFUs}\right)$, and this may be advantageous in food preservation as high concentration of acetic acid has been noted to be undesirable as it can impart negatively on sensory qualities [20].
3.2. Proximate Composition of Kunun-Aya. Presented in Table 1 is the result of proximate composition of starter culture inoculated samples (SCIS) and uninoculated samples (US) of kunnu-aya. The fat and carbohydrate contents were lower than $4.0 \%$ in all samples. It was also shown that the SCIS had higher contents of ash than their US counterparts; the highest content of $4.43 \%$ was recorded for SCIS made from fifty percent each of sorghum and tigernut (50SOR/50TIG) while the lowest $(2.05 \%)$ was obtained for the USS from one hundred percent sorghum (100SOR/0TIG). The enhanced values of ash contents noted in kunnu-aya samples inoculated with L. plantarum as starter culture in this study corroborate previous reports in which different foods were inoculated with cultures of LAB [21-23]. The trend of protein contents in the kunun-aya samples was similar to that of ash contents; the SCIS had higher contents than their US counterparts. There was significant difference in the values of ash and protein between the inoculated and uninoculated samples $(p<0.05)$. In a research investigation reported by Maiangwa et al. [22] on a food product (masa) inoculated with LAB starter cultures, higher values of protein contents were observed in the inoculated product than the uninoculated control sample. In another report, Akabanda et al. [23] investigated the effect of inoculating nunu (a fermented milk product in Ghana) with cultures of LAB and concluded that there was increased content of protein in inoculated samples over their uninoculated control counterparts. The enhanced contents of ash and protein recorded in the kununaya samples inoculated with $L$. plantarum may therefore be nutritionally advantageous to consumers of the product. This could constitute an economically viable approach towards promoting food security in developing countries such as Nigeria, where food sources of protein are hardly affordable by the majority of people due to prevailing high poverty level. The possible nutritional benefit inherent in food products 
TABLE 2: Physicochemical properties of starter culture inoculated and uninoculated kunnu-aya.

\begin{tabular}{|c|c|c|c|c|}
\hline \multirow[b]{2}{*}{ Samples } & \multicolumn{4}{|c|}{ Physicochemical properties } \\
\hline & $\mathrm{pH}$ & $\begin{array}{c}\text { TTA } \\
\text { (\% lactic acid) }\end{array}$ & $\begin{array}{c}\mathrm{SG} \\
\left(\mathrm{g} / \mathrm{cm}^{3}\right)\end{array}$ & $\begin{array}{c}\text { TSS } \\
\left({ }^{\mathrm{o}} \text { Brix }\right)\end{array}$ \\
\hline \multicolumn{5}{|c|}{ Inoculated samples } \\
\hline 100SOR/0TIG & $4.62 \pm 0.01^{\mathrm{b}}$ & $0.61 \pm 0.15^{\mathrm{c}}$ & $1.02 \pm 0.03^{\mathrm{a}}$ & $9.80 \pm 0.08^{\mathrm{a}}$ \\
\hline 90SOR/10TIG & $4.56 \pm 0.21^{\mathrm{b}}$ & $0.68 \pm 0.32^{b}$ & $1.04 \pm 0.06^{\mathrm{a}}$ & $9.72 \pm 0.02^{\mathrm{e}}$ \\
\hline 80SOR/20TIG & $4.59 \pm 0.17^{\mathrm{b}}$ & $0.65 \pm 0.61^{c}$ & $1.03 \pm 0.05^{\mathrm{a}}$ & $9.69 \pm 0.07^{\mathrm{a}}$ \\
\hline 70SOR/30TIG & $4.51 \pm 0.43^{\mathrm{b}}$ & $0.62 \pm 0.43^{\mathrm{d}}$ & $1.04 \pm 0.09^{\mathrm{a}}$ & $9.63 \pm 0.14^{\mathrm{a}}$ \\
\hline 60SOR/40TIG & $4.32 \pm 0.47^{\mathrm{b}}$ & $0.68 \pm 0.36^{\mathrm{a}}$ & $1.03 \pm 0.22^{\mathrm{a}}$ & $9.51 \pm 0.21^{\mathrm{a}}$ \\
\hline 50SOR/50TIG & $4.45 \pm 0.81^{\mathrm{b}}$ & $0.92 \pm 0.71^{\mathrm{d}}$ & $1.05 \pm 0.11^{\mathrm{a}}$ & $9.35 \pm 0.09^{\mathrm{a}}$ \\
\hline \multicolumn{5}{|c|}{ Uninoculated samples } \\
\hline 100SOR/0TIG & $5.83 \pm 1.01^{\mathrm{a}}$ & $0.41 \pm 0.23^{\mathrm{c}}$ & $1.01 \pm 0.31^{\mathrm{a}}$ & $9.52 \pm 0.33^{\mathrm{a}}$ \\
\hline 90SOR/10TIG & $5.79 \pm 0.99^{\mathrm{a}}$ & $0.44 \pm 0.35^{\mathrm{b}}$ & $1.04 \pm 0.17^{\mathrm{a}}$ & $9.45 \pm 0.36^{\mathrm{a}}$ \\
\hline 80SOR/20TIG & $5.74 \pm 1.28^{\mathrm{a}}$ & $0.40 \pm 0.35^{\mathrm{c}}$ & $1.03 \pm 0.04^{\mathrm{a}}$ & $9.53 \pm 0.12^{\mathrm{a}}$ \\
\hline 70SOR/30TIG & $5.62 \pm 0.51^{\mathrm{a}}$ & $0.35 \pm 0.39^{\mathrm{e}}$ & $1.04 \pm 0.08^{\mathrm{a}}$ & $9.61 \pm 0.07^{\mathrm{a}}$ \\
\hline $60 \mathrm{SOR} / 40 \mathrm{TIG}$ & $5.66 \pm 0.53^{\mathrm{a}}$ & $0.55 \pm 0.44^{\mathrm{a}}$ & $1.05 \pm 0.14^{\mathrm{a}}$ & $9.43 \pm 0.26^{\mathrm{a}}$ \\
\hline 50SOR/50TIG & $5.78 \pm 0.61^{\mathrm{a}}$ & $0.38 \pm 0.46^{\mathrm{d}}$ & $1.07 \pm 0.11^{\mathrm{a}}$ & $9.51 \pm 0.25^{\mathrm{a}}$ \\
\hline
\end{tabular}

Values are means of three replicated samples. Means with different superscript letters across columns are significantly different $(p<0.05)$; TTA, total titratable acidity; SG, specific gravity; TSS, total soluble solids; 100SOR/0TIG, $100 \%$ sorghum and $0 \%$ tigernut; 90 SOR/10TIG, $90 \%$ sorghum and $10 \%$ tigernut; $80 \mathrm{SOR} / 20 \mathrm{TIG}, 80 \%$ sorghum and $20 \%$ tigernut; $70 \mathrm{SOR} / 30 \mathrm{TIG}, 70 \%$ sorghum and $30 \%$ tigernut; $60 \mathrm{SOR} / 40 \mathrm{TIG}, 60 \%$ sorghum and $40 \%$ tigernut; 50SOR/50TIG, 50\% sorghum and 50\% tigernut.

inoculated with lactic acid bacteria was also demonstrated in the research finding of Agarry et al. [21] where kunun-zaki (produced from millet) was inoculated with LAB cultures. The ash and protein contents of the uninoculated kunun-aya samples were similar to those reported by Olaoye et al. [2] in a recent report on kunun-zaki produced from millet, with inclusion of tigernut milk extract.

3.3. Physicochemical Properties of Kunnu-Aya. Table 2 shows the results of the physicochemical properties of the kununaya samples. $\mathrm{pH}$ value below 5.0 was recorded for SCIS, whereas US samples had $\mathrm{pH}$ values higher than 5.0. There was significant difference $(p<0.05)$ between the $\mathrm{pH}$ of both SCIS and US samples. The lower $\mathrm{pH}$ in SCIS could be as a result of production of organic acids by $L$. plantarum used as starter culture, leading to lowering in $\mathrm{pH}$. LAB cultures are known to produce organic acids which bring about lowering of $\mathrm{pH}$ in foods inoculated with them [11,21]. The higher content of titratable acidity recorded in SCIS compared to US is a justification of the lower $\mathrm{pH}$ noted in the former than in the latter samples. Titratable acidity of a food product is a measure of lactic acid in it, and this has a direct effect on $\mathrm{pH}$. The values recorded for titratable acidity and $\mathrm{pH}$ of the kunun-aya samples in the present study were supportive of those reported in separate findings by Agarry et al. [21] and Olaoye et al. [2] in kunun-zaki. The values recorded for specific gravity (SG) and total soluble solids (TSS) of the kunun-aya samples did not show any significant difference $(p<0.05)$; that is, SCIS and US samples did not differ significantly from one another. The TSS ( ${ }^{\circ}$ Brix) was highest in the whole sorghum sample (100SOR/0TIG), having the value of 9.80 while the lowest value (9.35) was obtained for sample produced from fifty percent each of sorghum and tigernut (i.e., 50SOR/50TIG).
The TSS of the kunun-aya samples in this study were similar to those reported by Akoma et al. [1]; according to the author, a value of 9.07 was obtained as TSS for kunun-zaki produced from millet. The values of SG obtained in the present report were lower than those reported in a study reported by Olaoye et al. [2] from kunun-zaki produced from millet. The authors reported values lower than $1.0 \mathrm{~g} / \mathrm{cm}^{3}$, whereas values were higher than 1.0 in the present study; this could be attributed to the difference in cereal types and methods adopted during production of the nonalcoholic drink.

3.4. Microbial Counts of Kunnu-Aya. The microbial counts ( $\log$ CFUs/ml) of the kunun-aya samples are shown in Table 3. Values of total bacteria count (TBC) were higher in the USA in comparison with SICS, suggesting possible antimicrobial effect of $L$. plantarum on the microflora of the product. The highest TBC of 5.8 was recorded for the uninoculated sample made from fifty percent each of sorghum and tigernut while the lowest (2.2) was obtained for 90SOR/10TIG (i.e., sample made from $90 \%$ sorghum and $10 \%$ tigernut). A similar trend to those of TBC was observed for the yeast and mold $(\mathrm{Y} \& \mathrm{M})$ count in the nonalcoholic beverage. Although the antimicrobial activities of the $L$. plantarum used as starter culture were not demonstrated in this study, the lower counts of TBC and Y \& M recorded in the product may be attributed to production of antimicrobial agents by the LAB strain. This was because production of antimicrobial agents such as lactic acid, diacetyl, hydrogen peroxide, and bacteriocin by LAB such as $L$. plantarum against other microorganisms has been demonstrated in other research investigations [24-26]. The $L$. plantarum was also believed to display antimicrobial activity against Salmonella spp. in the beverage, as lower counts were recorded in samples inoculated with the starter culture than 
TABLE 3: Microbial counts (log CFUs/ml) of starter culture inoculated and uninoculated kunnu-aya.

\begin{tabular}{|c|c|c|c|c|c|c|}
\hline \multirow{2}{*}{ Samples } & \multicolumn{6}{|c|}{ Microorganisms enumerated } \\
\hline & TBC & Y \& M & Salmonella & Coliforms & Staphylococci & LAB \\
\hline \multicolumn{7}{|c|}{ Inoculated samples } \\
\hline 100SOR/0TIG & $2.8^{\mathrm{b}}$ & $1.5^{\mathrm{c}}$ & $2.8^{\mathrm{b}}$ & ND & ND & $6.8^{\mathrm{b}}$ \\
\hline 90SOR/10TIG & $2.2^{\mathrm{c}}$ & $2.0^{\mathrm{c}}$ & $2.5^{\mathrm{c}}$ & ND & ND & $7.2^{\mathrm{a}}$ \\
\hline 80SOR/20TIG & $2.7^{\mathrm{c}}$ & $2.7^{\mathrm{b}}$ & $2.7^{\mathrm{b}}$ & ND & ND & $7.4^{\mathrm{a}}$ \\
\hline 70SOR/30TIG & $2.9^{\mathrm{b}}$ & $2.2^{\mathrm{c}}$ & $2.0^{\mathrm{c}}$ & ND & ND & $6.9^{\mathrm{b}}$ \\
\hline $60 \mathrm{SOR} / 40 \mathrm{TIG}$ & $2.8^{\mathrm{b}}$ & $2.4^{\mathrm{c}}$ & $2.9^{\mathrm{b}}$ & ND & ND & $7.8^{\mathrm{a}}$ \\
\hline 50SOR/50TIG & $2.5^{\mathrm{c}}$ & $2.9^{\mathrm{b}}$ & $2.3^{c}$ & ND & ND & $8.5^{\mathrm{a}}$ \\
\hline \multicolumn{7}{|c|}{ Uninoculated samples } \\
\hline 100SOR/0TIG & $3.9^{\mathrm{b}}$ & $3.3^{\mathrm{b}}$ & $3.7^{\mathrm{a}}$ & $2.7^{\mathrm{b}}$ & $3.1^{\mathrm{b}}$ & $5.4^{\mathrm{c}}$ \\
\hline 90SOR/10TIG & $3.6^{\mathrm{b}}$ & $3.9^{\mathrm{a}}$ & $3.5^{\mathrm{b}}$ & $3.1^{\mathrm{a}}$ & $3.7^{\mathrm{a}}$ & $5.1^{\mathrm{c}}$ \\
\hline $80 \mathrm{SOR} / 20 \mathrm{TIG}$ & $5.3^{\mathrm{a}}$ & $3.7^{\mathrm{a}}$ & $3.2^{\mathrm{b}}$ & $3.4^{\mathrm{a}}$ & $4.0^{\mathrm{a}}$ & $5.2^{c}$ \\
\hline 70SOR/30TIG & $5.5^{\mathrm{a}}$ & $3.5^{\mathrm{a}}$ & $3.9^{\mathrm{a}}$ & $2.8^{\mathrm{b}}$ & $3.5^{\mathrm{b}}$ & $4.9^{\mathrm{d}}$ \\
\hline $60 \mathrm{SOR} / 40 \mathrm{TIG}$ & $4.9^{\mathrm{a}}$ & $3.2^{\mathrm{b}}$ & $4.0^{\mathrm{a}}$ & $3.0^{\mathrm{a}}$ & $4.2^{\mathrm{a}}$ & $5.3^{\mathrm{c}}$ \\
\hline 50SOR/50TIG & $5.8^{\mathrm{a}}$ & $3.0^{\mathrm{b}}$ & $4.2^{\mathrm{a}}$ & $3.2^{\mathrm{a}}$ & $4.4^{\mathrm{a}}$ & $5.6^{\mathrm{c}}$ \\
\hline
\end{tabular}

Values are means of three replicated samples. Means with different superscript letters across columns are significantly different $(p<0.05)$; CFUs, colony forming units; TBC, total bacteria count; Y \& M, yeasts and molds; LAB, lactic acid bacteria; $100 \mathrm{SOR} / 0 \mathrm{TIG}, 100 \%$ sorghum and $0 \%$ tigernut; $90 \mathrm{SOR} / 10 \mathrm{TIG}$, $90 \%$ sorghum and $10 \%$ tigernut; 80 SOR/20TIG, $80 \%$ sorghum and $20 \%$ tigernut; 70 SOR/30TIG, $70 \%$ sorghum and $30 \%$ tigernut; 60 SOR/40TIG, $60 \%$ sorghum and $40 \%$ tigernut; 50 SOR/50TIG, 50\% sorghum and 50\% tigernut.

TABLE 4: Mean sensory scores of starter culture inoculated and uninoculated kunnu-aya.

\begin{tabular}{|c|c|c|c|c|c|}
\hline \multirow{2}{*}{ Samples } & \multicolumn{5}{|c|}{ Sensory properties } \\
\hline & Appearance & Aroma & Taste & Mouth feel & G. acceptability \\
\hline \multicolumn{6}{|c|}{ Inoculated samples } \\
\hline 100SOR/0TIG & $8.30 \pm 0.66^{\mathrm{a}}$ & $7.90 \pm 0.79^{\mathrm{a}}$ & $8.25 \pm 0.64^{\mathrm{a}}$ & $7.85 \pm 0.88^{\mathrm{a}}$ & $8.50 \pm 0.61^{\mathrm{a}}$ \\
\hline 90SOR/10TIG & $7.60 \pm 0.60^{b}$ & $7.85 \pm 0.59^{\mathrm{a}}$ & $8.00 \pm 0.46^{\mathrm{a}}$ & $8.05 \pm 0.76^{\mathrm{a}}$ & $8.25 \pm 0.44^{\mathrm{a}}$ \\
\hline 80SOR/20TIG & $8.15 \pm 0.75^{\mathrm{a}}$ & $7.70 \pm 0.47^{\mathrm{a}}$ & $7.90 \pm 0.72^{\mathrm{a}}$ & $7.80 \pm 0.70^{\mathrm{a}}$ & $8.20 \pm 0.52^{\mathrm{a}}$ \\
\hline 70SOR/30TIG & $7.70 \pm 0.73^{\mathrm{b}}$ & $7.55 \pm 0.51^{\mathrm{a}}$ & $7.95 \pm 0.51^{\mathrm{a}}$ & $7.95 \pm 0.76^{\mathrm{a}}$ & $8.20 \pm 0.52^{\mathrm{a}}$ \\
\hline 60SOR/40TIG & $7.85 \pm 0.67^{\mathrm{b}}$ & $7.70 \pm 0.66^{\mathrm{a}}$ & $8.10 \pm 0.64^{\mathrm{a}}$ & $8.15 \pm 0.67^{\mathrm{a}}$ & $8.40 \pm 0.50^{\mathrm{a}}$ \\
\hline 50SOR/50TIG & $7.85 \pm 0.75^{\mathrm{b}}$ & $7.70 \pm 0.57^{\mathrm{a}}$ & $8.15 \pm 0.67^{\mathrm{a}}$ & $7.75 \pm 0.64^{\mathrm{b}}$ & $8.05 \pm 0.39^{\mathrm{b}}$ \\
\hline \multicolumn{6}{|c|}{ Uninoculated samples } \\
\hline 100SOR/0TIG & $7.90 \pm 1.62^{b}$ & $7.80 \pm 1.06^{\mathrm{a}}$ & $7.75 \pm 1.74^{\mathrm{a}}$ & $7.65 \pm 1.42^{\mathrm{b}}$ & $7.85 \pm 1.90^{\mathrm{a}}$ \\
\hline 90SOR/10TIG & $7.05 \pm 1.36^{\mathrm{c}}$ & $6.90 \pm 1.33^{b c}$ & $6.60 \pm 1.43^{\mathrm{b}}$ & $7.30 \pm 1.42^{c}$ & $7.00 \pm 1.30^{\mathrm{b}}$ \\
\hline $80 \mathrm{SOR} / 20 \mathrm{TIG}$ & $7.75 \pm 1.12^{\mathrm{b}}$ & $7.10 \pm 1.07^{\mathrm{ab}}$ & $6.85 \pm 1.39^{\mathrm{b}}$ & $7.25 \pm 1.29^{c}$ & $7.60 \pm 1.14^{\mathrm{b}}$ \\
\hline 70SOR/30TIG & $7.25 \pm 1.21^{\mathrm{c}}$ & $6.25 \pm 1.29^{c}$ & $6.65 \pm 1.93^{\mathrm{b}}$ & $7.15 \pm 1.42^{c}$ & $7.00 \pm 1.72^{\mathrm{c}}$ \\
\hline $60 \mathrm{SOR} / 40 \mathrm{TIG}$ & $7.10 \pm 1.37^{\mathrm{c}}$ & $7.15 \pm 1.18^{\mathrm{ab}}$ & $7.30 \pm 1.53^{\mathrm{ab}}$ & $7.20 \pm 1.61^{c}$ & $7.40 \pm 1.50^{\mathrm{b}}$ \\
\hline 50SOR/50TIG & $7.20 \pm 1.51^{c}$ & $6.70 \pm 1.26^{\mathrm{bc}}$ & $7.60 \pm 1.14^{\mathrm{ab}}$ & $7.00 \pm 1.30^{c}$ & $7.15 \pm 1.14^{\mathrm{c}}$ \\
\hline
\end{tabular}

Values are means of three replicated samples. Means with different superscript letters across columns are significantly different $(p<0.05)$; G. acceptability, general acceptability; 100SOR/0TIG, 100\% sorghum and 0\% tigernut; 90SOR/10TIG, 90\% sorghum and 10\% tigernut; 80 SOR/20TIG, $80 \%$ sorghum and $20 \%$ tigernut; 70SOR/30TIG, 70\% sorghum and 30\% tigernut; 60SOR/40TIG, 60\% sorghum and 40\% tigernut; 50SOR/50TIG, 50\% sorghum and 50\% tigernut.

their uninoculated counterparts. Similar observations were recorded for coliforms and Staphylococci; the two groups of organisms were not detected in inoculated samples, unlike in uninoculated samples where counts were recorded. The antimicrobial activities of $L$. plantarum against Salmonella, coliforms, and Staphylococci in this study are in support of previous reported research investigations. For example, Akabanda et al. [23] reported antimicrobial activity of some strains of Lactobacillus against Staphylococcus typhi and S. aureus (members of Staphylococci) in nunu, a fermented milk product. Olanrewaju [27] and Okereke et al. [28] also demonstrated the antimicrobial activities of some LAB cultures against Escherichia coli (a member of coliforms) and $S$. aureus in in vitro experiments. Many members of Salmonella, coliforms, and Staphylococci are known to be associated with food-borne illness [23, 27-29] and are therefore of public health importance. The antimicrobial activities displayed by L. plantarum against these organisms could be very helpful in promoting safety and public health among consumers of the traditional food beverage, kunun-aya.

3.5. Sensory Evaluation of Kunnu-Aya. The result of the sensory evaluation of the kunnu-aya samples (Table 4) showed that the inoculated samples had higher mean scores than 
the uninoculated control counterparts in most of the sensory properties that were evaluated. The inoculated 100SOR/0TIG sample had highest mean scores of $8.30,7.90,8.25$, and 8.50 in the sensory properties of appearance, aroma, taste, and general acceptability. The highest score of 8.05 was however recorded for inoculated $90 \mathrm{SOR} / 10 \mathrm{TIG}$ sample in the sensory attribute of mouthfeel.

\section{Conclusion}

It was concluded that the use of L. plantarum culture in the production of kunun-aya gave enhanced nutritional quality especially in terms of ash and protein which may be beneficial to consumers of the product. The LAB culture displayed antagonistic activity against Staphylococci and Salmonella, and this is of public health significance in Nigeria where the beverage is normally consumed by a vast majority of the populace, especially in the northern part of the country.

\section{Conflicts of Interest}

The authors declare that there are no conflicts of interest regarding the publication of this paper.

\section{References}

[1] O. Akoma, A. A. Daniel, A. E. Ajewole, and P. G. Nwodo, "Quality characteristics of kunun zaki (a Nigerian fermented cereal beverage) sold within bida metropolis," Global Advanced Research Journal of Agricultural Science, vol. 3, pp. 298-303, 2014.

[2] O. A. Olaoye, S. C. Ubbor, and E. A. Uduma, "Determination of vitamins, minerals, and microbial loads of fortified nonalcoholic beverage (kunun zaki) produced from millet," Food Science and Nutrition, vol. 4, no. 1, pp. 96-102, 2016.

[3] C. U. Okoronkwo, "Isolation and Characterization of Lactic Acid Bacteria Involved In the Fermentation of Millet and Sorgum Sold In Nkwo-Achara Market, Abia State," Journal of Environmental Science Toxicology and Food Technology, vol. 8, no. 9, pp. 42-45, 2014.

[4] S. M. Adeyemo and A. A. Onilude, "Molecular identification of Lactobacillus plantarum isolated from fermenting cereals," in Proceedings of the International Journal of Biotechnology and Molecular Biology Research, vol. 5, pp. 59-67, 2014.

[5] A. A. Omode, O. S. Fatoki, and K. A. Olaogun, "Physicochemical properties of some underexploited and nonconventional oilseeds," Journal of Agricultural and Food Chemistry, vol. 43, no. 11, pp. 2850-2853, 1995.

[6] O. A. Olaoye, A. A. Onilude, and O. A. Idowu, "Microbiological Profile of Goat Meat Inoculated with Lactic Acid Bacteria Cultures and Stored at 30॰C for 7 days," Food and Bioprocess Technology, vol. 4, no. 2, pp. 312-319, 2011.

[7] P. Calo-Mata, S. Arlindo, K. Boehme, T. de Miguel, A. Pascoal, and J. Barros-Velazquez, "Current applications and future trends of lactic acid bacteria and their bacteriocins for the biopreservation of aquatic food products," Food and Bioprocess Technology, vol. 1, no. 1, pp. 43-63, 2008.

[8] M. T. Aymerich, M. Hugas, and J. M. Monfort, "Bacteriocinogenic lactic acid bacteria associated with meat products," Food
Science and Technology International, vol. 4, no. 3, pp. 141-158, 1998.

[9] A. A. Onilude, A. I. Sanni, O. A. Olaoye, and S. T. Ogunbanwo, "Influence of lactic cultures on the quality attributes of tsire, a West African stick meat," World Journal of Microbiology and Biotechnology, vol. 18, no. 7, Article ID 5092350, pp. 615-619, 2002.

[10] P. A. Maragkoudakis, K. C. Mountzouris, D. Psyrras et al., "Functional properties of novel protective lactic acid bacteria and application in raw chicken meat against Listeria monocytogenes and Salmonella enteritidis," International Journal of Food Microbiology, vol. 130, no. 3, pp. 219-226, 2009.

[11] O. A. Olaoye and A. A. Onilude, "Investigation on the potential application of biological agents in the extension of shelf life of fresh beef in Nigeria," World Journal of Microbiology and Biotechnology, vol. 26, no. 8, pp. 1445-1454, 2010.

[12] Y.-S. Chen, F. Yanagida, and J.-S. Hsu, "Isolation and characterization of lactic acid bacteria from suan-tsai (fermented mustard), a traditional fermented food in Taiwan," Journal of Applied Microbiology, vol. 101, no. 1, pp. 125-130, 2006.

[13] P.-M. Yan, W.-T. Xue, S.-S. Tan, H. Zhang, and X.-H. Chang, "Effect of inoculating lactic acid bacteria starter cultures on the nitrite concentration of fermenting Chinese paocai," Food Control, vol. 19, no. 1, pp. 50-55, 2008.

[14] L. Settanni and A. Corsetti, "Application of bacteriocins in vegetable food biopreservation," International Journal of Food Microbiology, vol. 121, no. 2, pp. 123-138, 2008.

[15] D. Hemme and C. Foucaud-Scheunemann, "Leuconostoc, characteristics, use in dairy technology and prospects in functional foods," International Dairy Journal, vol. 14, no. 6, pp. 467-494, 2004.

[16] O. A. Olaoye and A. A. Onilude, "Isolation and biochemical profiles of numerous strains of lactic acid producing bacteria from various parts of a domestic West African goat (Capra Hircus)," Australian Journal of Basic and Applied Sciences, vol. 3, no. 2, pp. 460-466, 2009.

[17] AOAC., Association of Official Analytical Chemists, Official methods of analysis of the Association of Analytical Chemists International, Gaithersburg, MD, USA, 18th edition, 2005.

[18] SPSS., Statistical Package for Social Sciences, SPSS 1001 for windows, SPSS Inc, Chicago, Illinois, USA, 1999.

[19] D. Djenane, L. Martínez, D. Blanco, J. Yangüela, J. A. Beltrán, and P. Roncalés, "Effect of lactic acid bacteria on extention of shelf life and growth of Listeria monocytogenes in beef steaks stored in CO2-rich atmosphere," Brazilian Journal of Microbiology, vol. 36, no. 4, pp. 405-412, 2005.

[20] M. S. Ammor and B. Mayo, "Selection criteria for lactic acid bacteria to be used as functional starter cultures in dry sausage production: an update," Meat Science, vol. 76, no. 1, pp. 138-146, 2007.

[21] O. O. Agarry, I. Nkama, and O. Akoma, "Production of Kununzaki (A Nigerian fermented cereal beverage) using starter culture," International Research Journal of Microbiology, vol. 1, pp. 018-025, 2010.

[22] J. S. Maiangwa, A. Orukotan, and F. Saibu, "Effect of yeast and lactic acid bacteria on nutritional and sensory quality of Masa (a fermented snack)," Pakistan Journal of Nutrition, vol. 12, no. 7, pp. 655-659, 2013

[23] F. Akabanda, J. Owusu-Kwarteng, K. Tano-Debrah, C. Parkouda, and L. Jespersen, "The use of lactic acid bacteria starter culture in the production of Nunu, a spontaneously fermented 
milk product in Ghana," International Journal of Food Science, vol. 2014, Article ID 721067, 2014.

[24] F.-K. Lücke, "Utilization of microbes to process and preserve meat," Meat Science, vol. 56, no. 2, pp. 105-115, 2000.

[25] O. Olaoye, "Technological Properties of Lactococcus lactis subsp. lactis I23 Isolated from Nigerian Beef and Characterization of Bacteriocin Produced by It," British Biotechnology Journal, vol. 4, no. 7, pp. 829-845, 2014.

[26] O. A. Olaoye, A. A. Onilude, and S. C. Ubbor, "Control of Brochothrix thermosphacta in pork meat using Lactococcus lactis subsp. lactis I23 isolated from beef," Applied Food Biotechnology, vol. 2, pp. 49-55, 2015.

[27] O. Olanrewaju, "Antagonistic effect of lactobacillus isolates from kunnu and cowmilk on selected pathogenic microorganisms," Internet Journal of Food Safety, vol. 9, pp. 63-66, 2007.

[28] H. K. Okereke, O. K. Achi, U. N. Ekwenye, and F. A. Orji, "Antimicrobial properties of probiotic bacteria from various sources," African Journal of Biotechnology, vol. 11, pp. 9416-9421, 2012.

[29] O. A. Olaoye and A. A. Onilude, "Assessment of microbiological quality of sachet-packaged drinking water in Western Nigeria and its public health significance," Public Health, vol. 123, no. 11, pp. 729-734, 2009 b. 

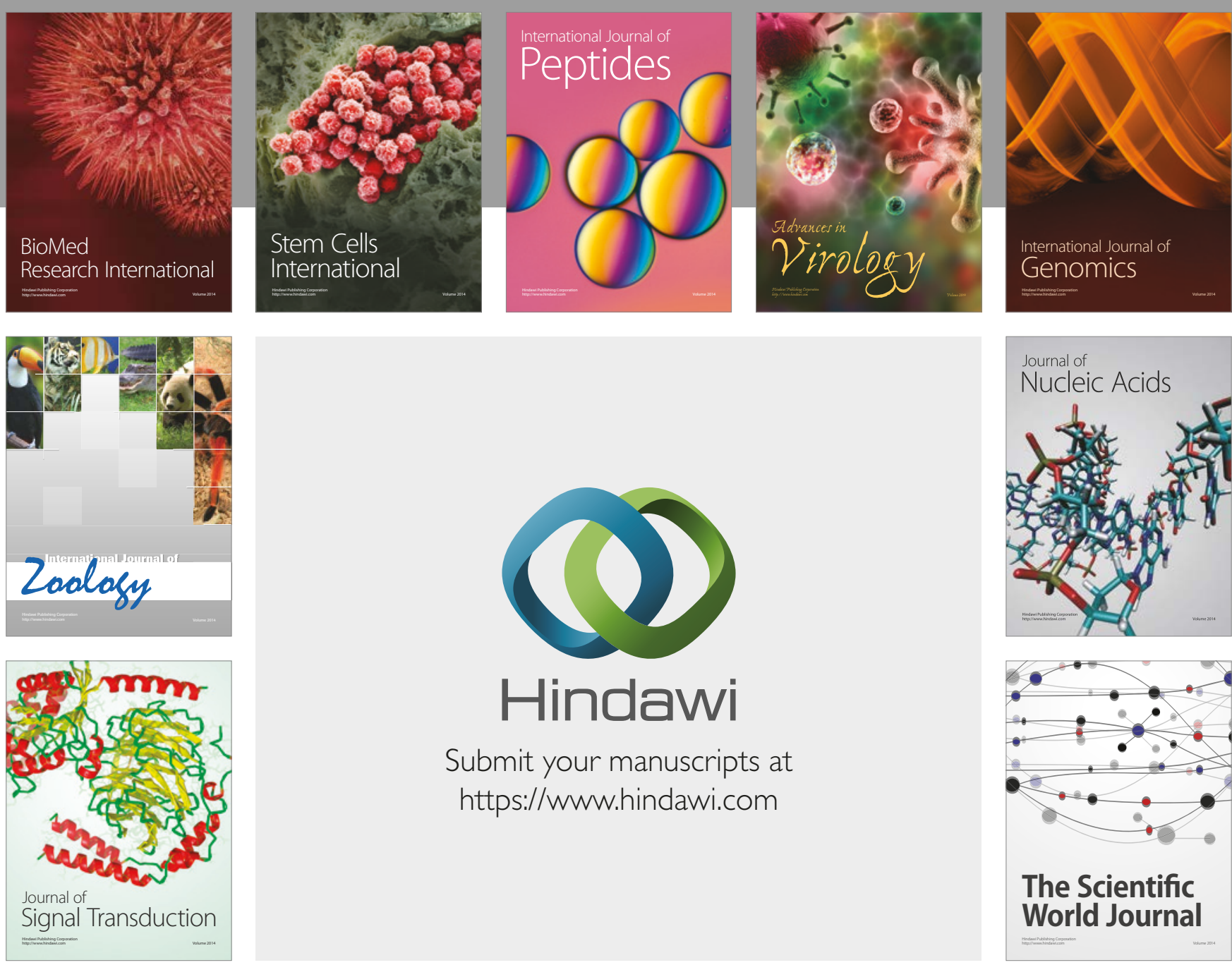

Submit your manuscripts at

https://www.hindawi.com
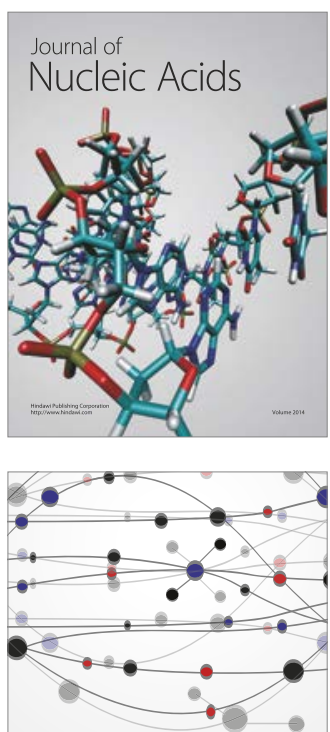

The Scientific World Journal

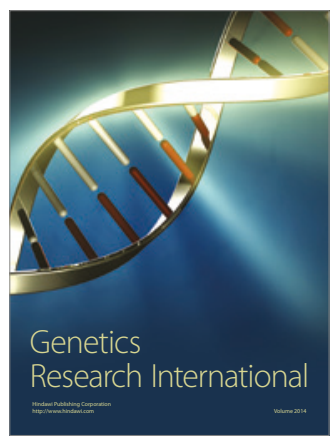

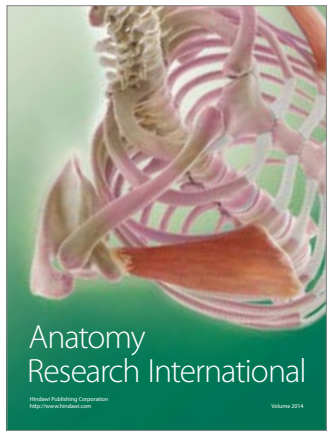

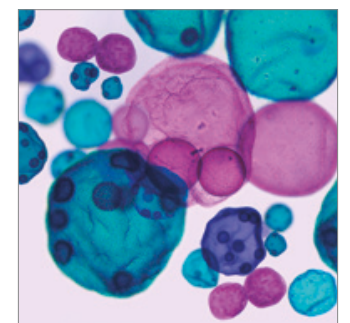

International Journal of Microbiology
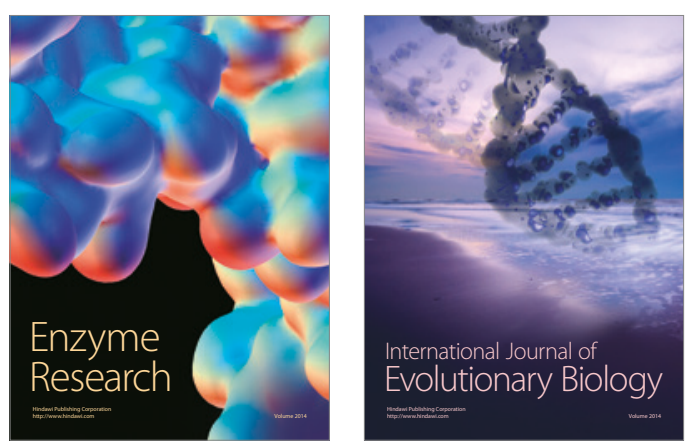
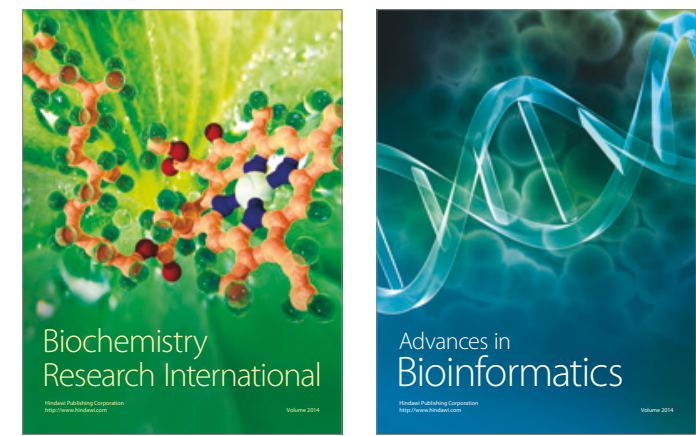

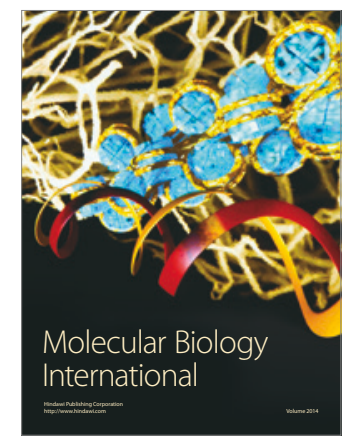

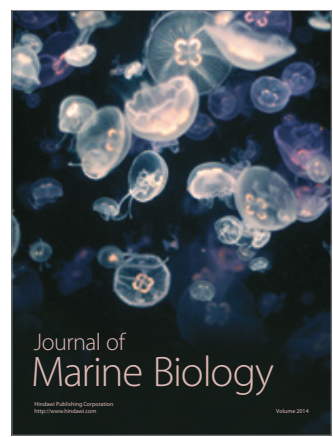

